\title{
Geomechanical characterization of lateritic hardpans from Bamendjou (West-Cameroon)
}

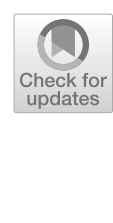

Y. Ngueumdjo ${ }^{1}$, V. H. Njuikom Djoumbi ${ }^{1}$, V. Y. Katte ${ }^{2^{*}}$ (D) F. Ngapgue ${ }^{3}$ and A. S. L. Wouatong ${ }^{1}$

*Correspondence:

vkatte@unam.na

2 Department of Civil \&

Environmental Engineering,

FEIT, University of Namibia,

P.O Box 3624, Ongwediva,

Namibia

Full list of author information

is available at the end of the article

\begin{abstract}
This study reports on the physical, mechanical, mineralogical and geochemical analysis carried out on four lateritic hardpan specimens from quarries in the Bamendjou area in the Western Region of Cameroon using common prescribed procedures. The results indicate that values of the bulk density, specific gravity, total and open porosities are very variable from one specimen to another. Meanwhile, the value of the compressive strengths of both the dry and immersed specimens were also very variable from one specimen to another, with the F2 and F1 specimens having higher values than the A1 and $A 2$ specimens. All the specimens immersed in water recorded lower compressive strengths than the dry specimens. The flexural strengths also varied from one sample to another, with the F2 specimen having the highest resistance. The X-ray diffraction patterns reveal that the major peaks were assigned to gibbsite, goethite, and hematite, while the minor peaks were assigned to kaolinite and anatase. The mineralogy and geochemistry influenced the physical and mechanical properties, with the iron rich specimens having higher values in both the physical and mechanical properties than the alumina rich specimens. The results of the compressive strengths obtained were higher than (1-4) MPa obtained in Burkina Faso and India where they have been using latertic blocks for construction. Thus the hardpans of Bamendjou can also be exploited for building purposes conveniently.
\end{abstract}

Keywords: Bamendjou, Building purposes, Lateritic hardpans, Physical, Mechanical mineralogical, Geochemical characteristics

\section{Introduction}

Lateritic hardpans are residual products of the laterization process from the parent rock developed in humid, tropical and subtropical regions of the world having good drainage. The combination of certain pedogenenic factors such as precipitation, temperature, seasonal variation and land morphology leads to the development of a weathering mantle which results in the formation of hardpan horizons within the soil profile. Buchanan [1] was the first to identify and name this soil laterite from the latin word "later" meaning brick. Since it can be cut into bricks, it is often utlised as building stones in some tropical and subtropical regions of the world where it is readily available and it is economical compared to other natural stones [2]. In Cameroon, research on laterites and lateritic soil, started at the beginning of the twentieth century [3, 4] with many studies carried author(s) and the source, provide a link to the Creative Commons licence, and indicate if changes were made. The images or other third party material in this article are included in the article's Creative Commons licence, unless indicated otherwise in a credit line to the material. If material is not included in the article's Creative Commons licence and your intended use is not permitted by statutory regulation or exceeds the permitted use, you will need to obtain permission directly from the copyright holder. To view a copy of this licence, visit http:// creativecommons.org/licenses/by/4.0/. 
out on laterite for mining purposes $[5,6]$ while for road construction $[7,8]$ have carried out some useful studies. However, very little work has been done on the utilization of the lateritic hardpans in masonry, meanwhile, in India and Burkina Faso, a good number of studies where carried out with the development of specifications for the use of lateritic hardpans in masonry [9-11]. In spite of the existence of many works related to the utilization of laterite for building applications in others areas of the world, there are no available information of similar utilization in Cameroon, in spite of its relative abundance in the country. Demographic pressure is now giving impetus to use non-conventional materials for building purposes and lateritic hardpans is among the plethora of these materials which can be utilized for sustainable construction practice. The Bamendjou vicinity contains one of the vast unexploited laterite deposits of Cameroon. It is therefore exigent to have relevant scientific knowledge of the characteristics of these hardpans if it is intended for building purposes.

\section{Materials and methods}

\section{The site setting}

The study area is located between longitudes $10^{\circ} 10^{\prime}$ and $10^{\circ} 20^{\prime}$ East and latitudes $5^{\circ} 20^{\prime}$ and $5^{\circ} 30^{\prime}$ North (Fig. 1). It belongs to Bamendjou subdivision which is located in the Hauts Plateaux Division of the West Region and has a surface area of $45 \mathrm{~km}^{2}$. Geologically, Bamendjou falls within what is popularly referred to as the Bamiléké Plateau situated within the Western highlands of Cameroon and located in the central part of Cameroon Volcanic Line $(C V L)$. In this region, the lateritic hardpans or duricrust were developed exclusively from the aphyric or porphyric basalts [12]. The vegetation is an anthropic savanna known as the Grassfield of Western Cameroon. The hydrography of the area shows a subparallel drainage pattern as shown in Fig. 2.

\section{Materials and methods}

\section{Materials}

The lateritic hardpans were obtained from three quarries located in Bamendjou as shown in Fig. 2. The Nkong-Kang (NK) quarry is located at an elevation of $1628 \mathrm{~m}$ at a latitude of $05^{\circ} 21^{\prime} 9^{\prime \prime}$ North and longitude $10^{\circ} 08^{\prime} 12^{\prime \prime}$ East. At this position the lateritic hardpans outcrops to the surface. The Nkong Dang (ND) is at an elevation $1633 \mathrm{~m}$ at a latitude of $05^{\circ} 23^{\prime} 22^{\prime \prime}$ North and longitude $10^{\circ} 20^{\prime} 14$ "East. The Nkong-T'honta (NT) quarry is located at an elevation of $1566 \mathrm{~m}$ at a latitude of $05^{\circ} 22^{\prime} 14^{\prime \prime}$ North and longitude $10^{\circ} 20^{\prime} 26^{\prime \prime}$ East. The specimens of each of the various lateritic hardpans obtained from the quarries are shown in Fig. 3. The lateritic blocks were hewn out with a combination of rudimentary equipment such as pick axes, shovels and and an electric saw, after which they were then cut into blocks. Each of these blocks were rapped in cellophane paper then wax sealed and then rapped again with another layer of cellophane paper for transportation to the laboratory. In all four samples were collected, comprising two from Nkong-Kang (NK) quarry (A1 and F2) and one sample sample from each of the other quarries, Nkong-Dang (ND) and Nkong-T'honta (NT) which were labelled as (A2 and F1) respectively. Each of these were shipped to the Faculty of Applied Sciences of the University of Liege in Belguim, where they were further cut to the required sizes with the aid of diamond tipped saw. 


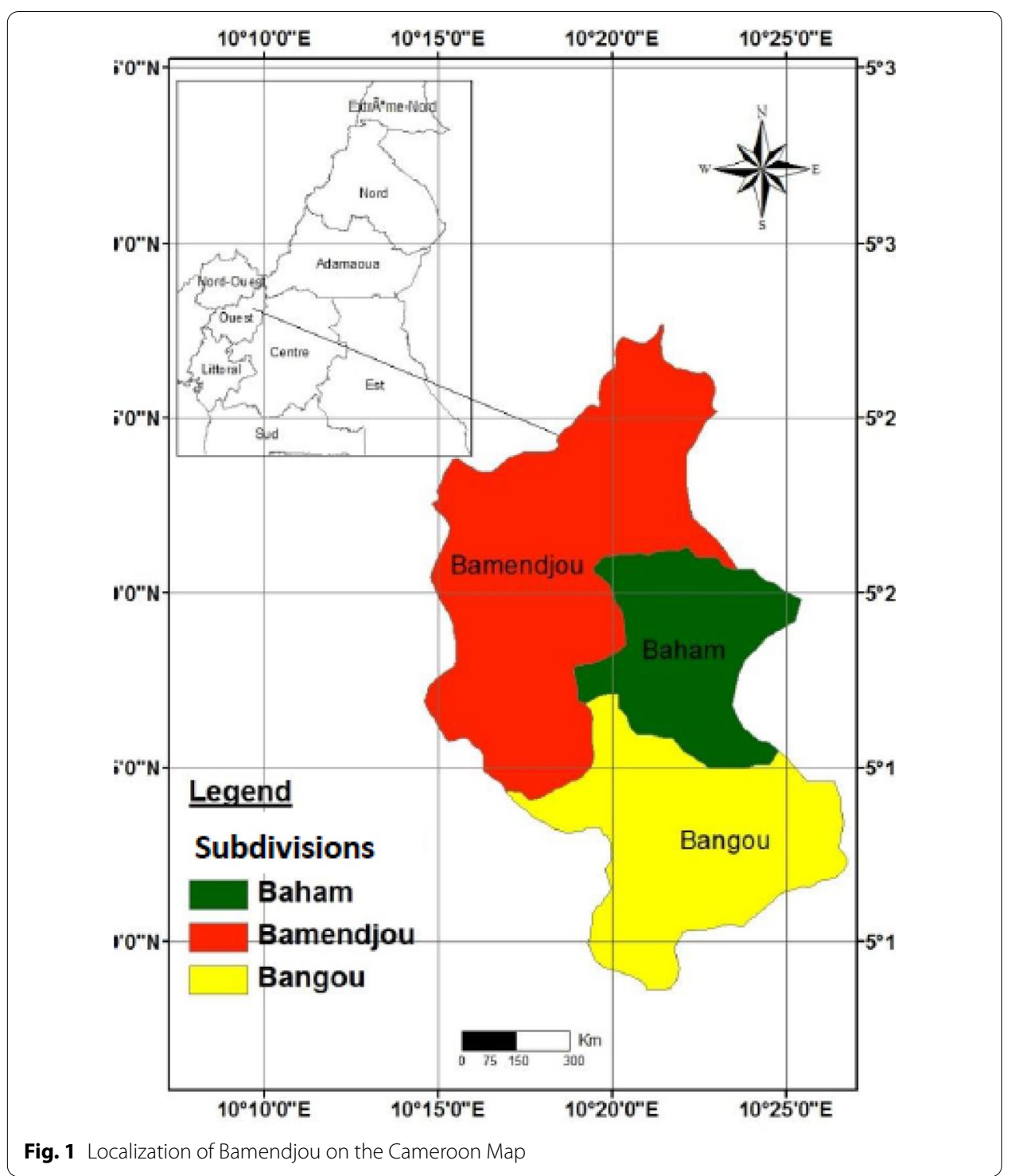

\section{Physical analysis}

The following physical analysis were carried out on the specimens: water content, specific gravity, bulk density, total porosity, open porosity and the degree of saturation using different but prescribed techniques. The water content test was performed in accordance with the French standards NF P94-050 [13]. The specific gravity (Gs) was determined according to the standard NF EN ISO 8130-2 (2011) using the pycnometer with gas (Helium). The bulk density $(\rho)$ and porosity $\left(\mathrm{P}_{\mathrm{o}}\right)$ were calculated using the hydrostatic method in accordance with the EN 1936: [14] standard expressed as

$$
\rho=\frac{m_{0}}{\left(m_{s}-m_{h}\right)} \rho_{w}\left(g / m^{3}\right)
$$

where " $\mathrm{m}_{0}$ " is the dry weight of the specimen, " $\mathrm{m}_{\mathrm{s}}$ " is the saturation weight, " $\mathrm{m}_{\mathrm{h}}$ " is the hydrostatic weight (immersed in water) and " $\rho_{\omega}$ " the density of water. 


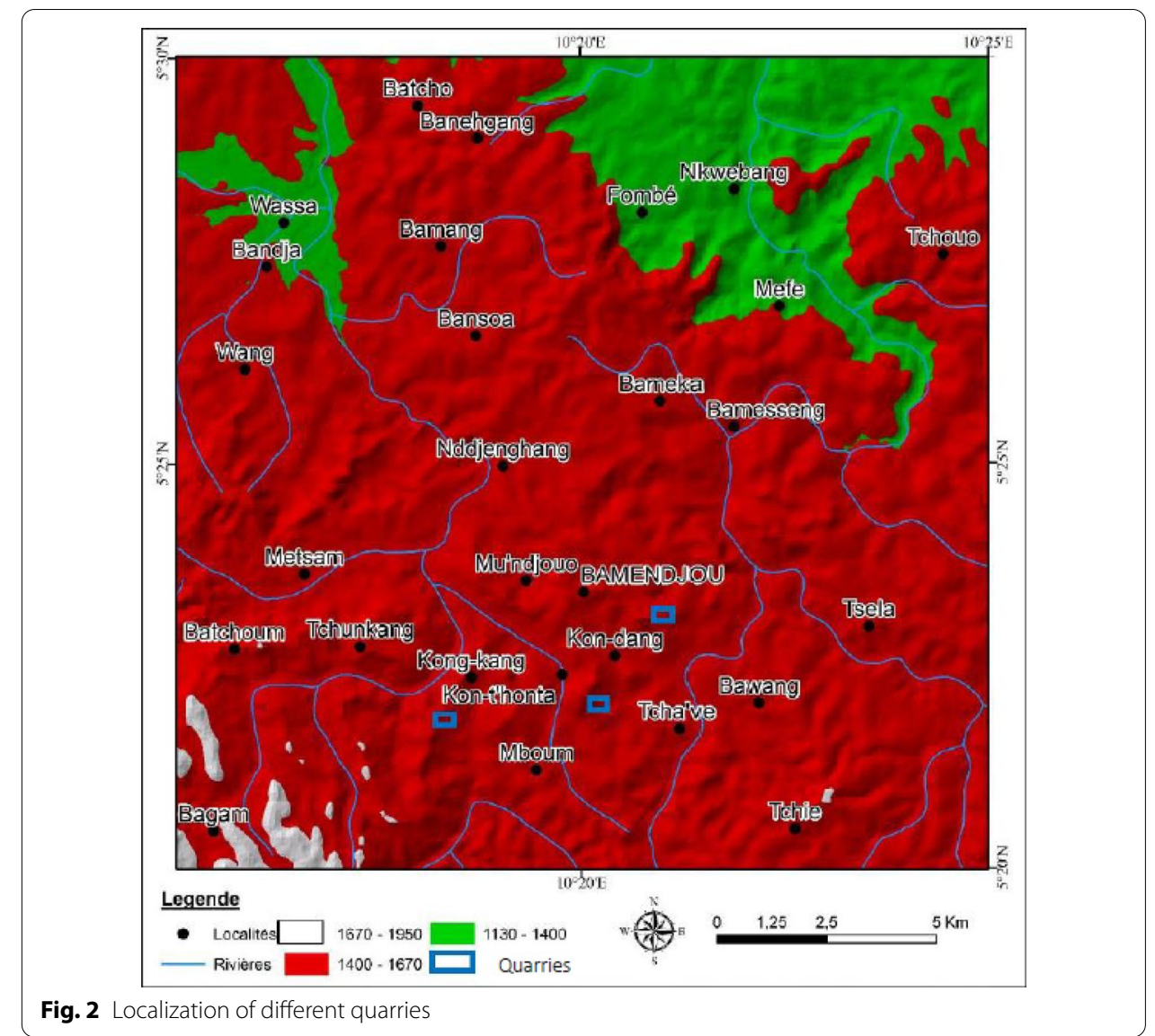

Total porosity $(\mathrm{N})$, open porosity $\left(\mathrm{N}_{0}\right)$ and saturation ratio $(\mathrm{S})$ were calculated as follows:

$$
\begin{aligned}
& \mathrm{N}=\left(\frac{\left(\mathrm{G}_{\mathrm{s}}-\rho\right)}{\mathrm{G}_{\mathrm{s}}}\right) * 100(\%) \\
& \mathrm{N}_{0}=\left(\frac{\left(\mathrm{m}_{\mathrm{s}}-\mathrm{m}_{0}\right)}{\left(\mathrm{m}_{\mathrm{s}}-\mathrm{m}_{\mathrm{h}}\right)}\right) * 100(\%) \\
& \mathrm{S}=\frac{\mathrm{N}_{0}}{\mathrm{~N}}(\%)
\end{aligned}
$$

\section{Mechanical analysis}

Compressive strength testing was performed on six specimens of dimensions $5 \mathrm{~cm} \times 5 \mathrm{~cm} \times 5 \mathrm{~cm}$ while flexural strength testing was carried out on specimens of dimensions $5 \mathrm{~cm} \times 2.5 \mathrm{~cm} \times 15 \mathrm{~cm}$. Figure 4(a) shows the experimental set-up of the compressive testing device while Fig. 4(b) shows the flexural strength testing device and Fig. $4 \mathrm{c}-\mathrm{e}$ are the various specimens to be tested. The compressive strength was performed on specimens that were dry as well as specimens that were immersed in water. The immersed samples were in water for $192 \mathrm{~h}$ after which they were air dried 


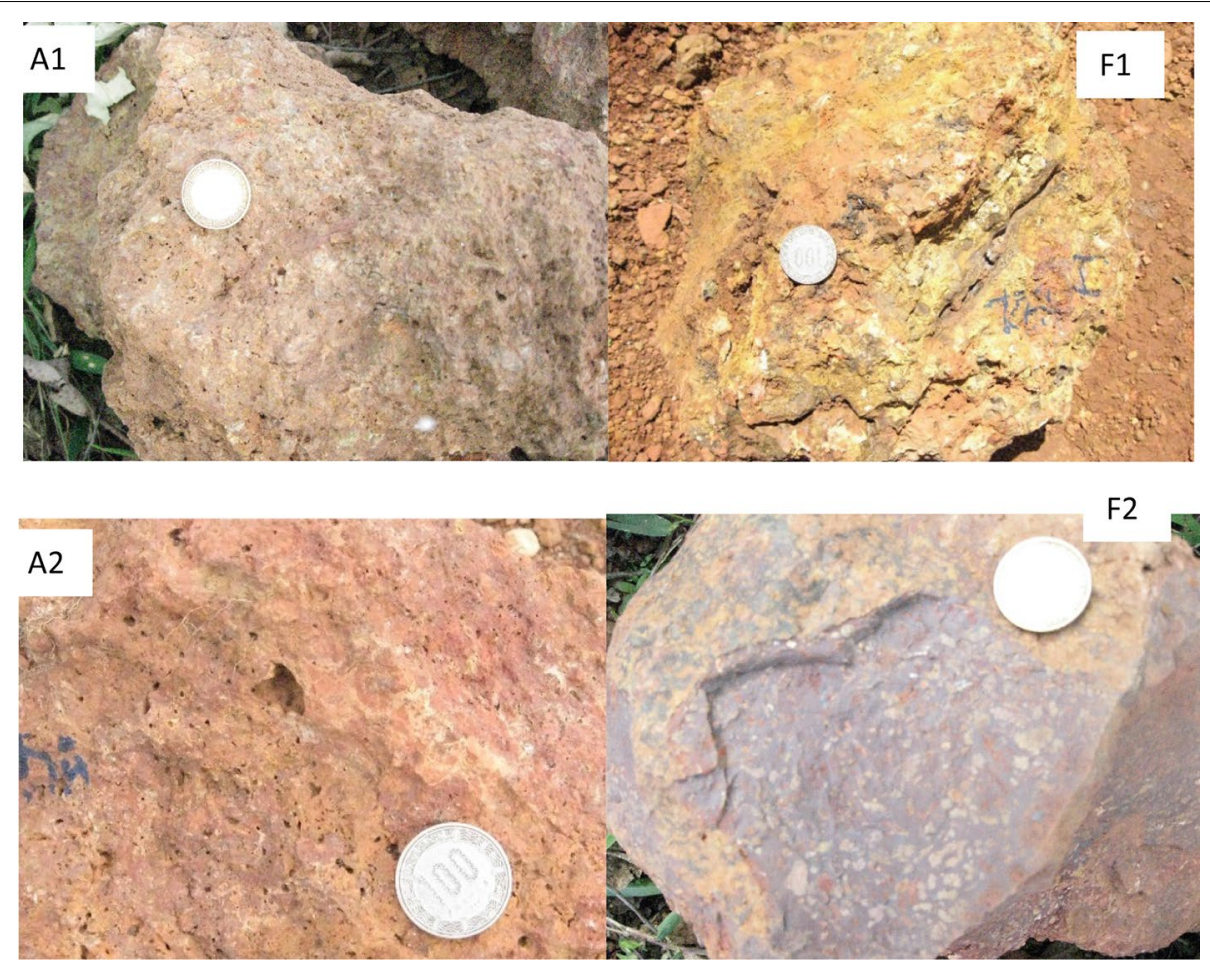

Fig. 3 Samples of lateritic hardpans from the various quarries

a
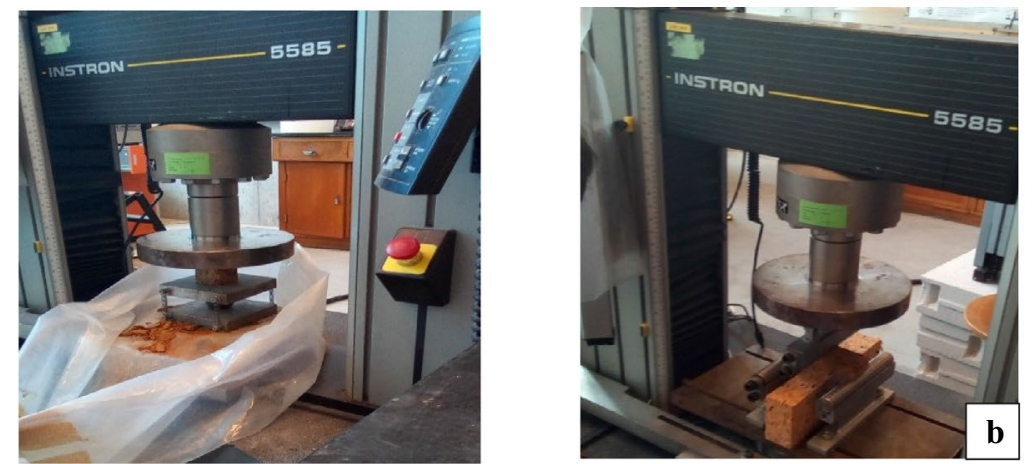

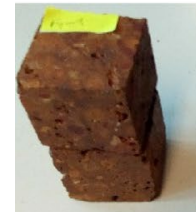

F1

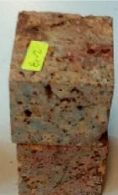

A1

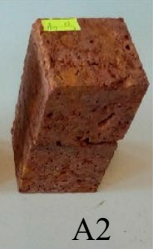

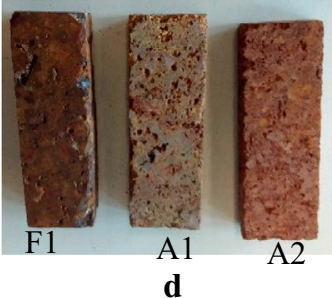

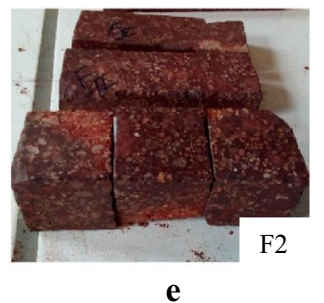

Fig. 4 a compressive strength device, $\mathbf{b}$ flexural strength device, $\mathbf{c}-\mathbf{e}$ are the specimens for testing 
for $48 \pm 2 \mathrm{~h}$ (EN 13722 [15]) before testing, using a monoaxial compression method on an Instron 5585 universal testing machine, in accordance with the European norms EN 1926 [16]. The flexural strength was obtained using the same device as above, in accordance with the European norms EN 12372 [17].

\section{Mineralogical and geochemical analyses}

The mineralogical analysis was carried out by X-ray diffraction using the Bruker D8 Advance diffractometer. The crushed samples were scanned using monochromatic $\mathrm{Cu}$ Ka radiation with 26 ranges of $2^{\circ}-70^{\circ}$ in steps of $0.020^{\circ}$ operated at $40 \mathrm{kV}$ and $25 \mathrm{~mA}$ using $\mathrm{Cu}-\mathrm{K} \alpha 1$ radiation $(\mathrm{I}=1.5406 \mathrm{~A})$. The interpretation of the mineral phases was carried out in accordance with [18] with the aid of the EVA software which contains a Powder Diffraction File for mineral identification.

\section{Results and discussions}

\section{Physical properties}

The results of the physical parameters determined in the laboratory comprising of the bulk density, specific gravity, natural water content, open and total porosity of the specimens are presented in Table 1 . The values of the bulk density are very variable from one specimen to another ranging from 1.88 to $3.01 \mathrm{~g} / \mathrm{cm}^{3}$. The specific gravity are also very high and variable from one quarry to another ranging from a value of 2.8 to 3.84. It was observed that the natural water content was very low in all the specimens as shown in Table 1. The porosity of a material, is a measure of the void or empty spaces available in a material. Two porosity terms are often utilized which are the total porosity and open porosity. In this study the both open and total porosity parameters of the specimens varied from one specimen to the other within the same quarry. Similar results were observed by Lawane et al. [19]; Vasquez et al. [20] and Kasthurba et al. [21] on blocks of laterites destined for construction purposes. The differences between values of total porosity may be due to differences in the porous system. The open porosity accounts for $30 \%$ to $63 \%$ of the total porosity resulting in the degree of saturation being much lower than $100 \%$. This means that the material has a significant occluded porosity Brown [18]. Lawane et al. [19], reported that in laterites, occluded porosity plays an important role in the resistance of rocks as well as of its degradation, depending if the voids are connected or continuous.

Table 1 Mineralogical composition of the lateritic hardpans of Bamendjou

\begin{tabular}{lllllll}
\hline Quarry & Samples & \multicolumn{2}{l}{ Minerals (\%) } & & \\
\cline { 3 - 7 } & & Goethite & Hematite & Gibbsite & Anatase & Kaolinite \\
\hline Nkong-Thonta & F1 & 60.96 & 6.90 & 16.66 & 1.94 & 13.54 \\
Nkong-Kang & F2 & 13.13 & 48.04 & 26.66 & 2.37 & 6.79 \\
& A1 & 10.45 & 1.53 & 81.58 & 3.69 & 2.58 \\
Nkong-Ndang & A2 & 20.59 & 6.79 & 66.39 & 3.33 & 2.91 \\
\hline
\end{tabular}




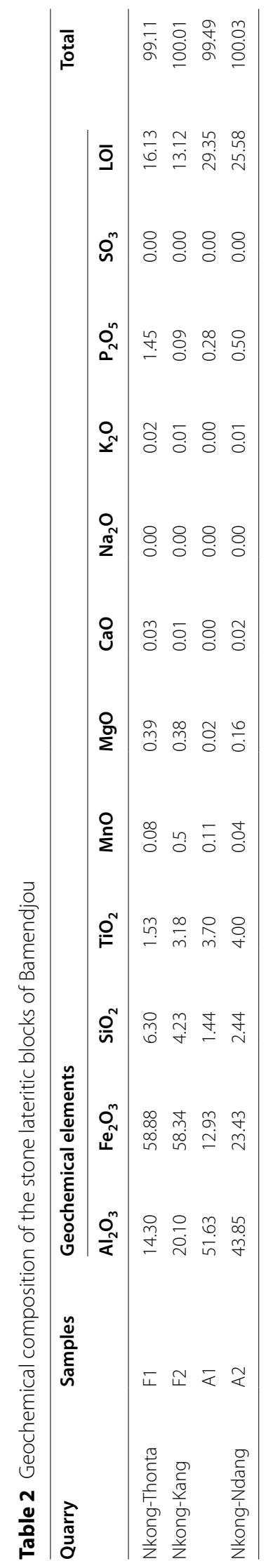




\section{Mechanical properties}

The results obtained from the uniaxial compressive strength tests and the three point flexural strength tests are presented in Table 2. The samples were tested dry as well as immersed in water. The values of the compressive strength tested dry as well as immersed were very variable from one specimen to another. The values of samples F2 (75.97 and 75.7) $\mathrm{MPa}$ and $\mathrm{F} 1$ (32.18 and 23.15) MPa, were very high compared with those of the specimen A1 (22.73 and 8.79) MPa and A2 (13.89 and 5.51) MPa. However, we also note very significant variables within the same specimen (Fig. 5a; b). The resistance of the specimens that were immersed in water decreased considerably in all the specimens except for the F2 specimens. The compressive strength of lateritic stone blocks (LBS) obtained in Burkina Faso and India gave strength values between 1.5-4.0 MPa [11, 21]. Meanwhile the European standards EN 777-1 [22] precribes a minimum of $2.3 \mathrm{MPa}$ for the compressive strength of bricks. Therefore all the specimens can be utilized safely for the construction of dwelling units since the minimum compressive strength of the hardpans tested dry was $13.89 \mathrm{MPa}$. The flexural strength also varied from one sample to another, with the F2 specimen having the highest resistance $(15.51 \mathrm{MPa})$. The lowest value of flexural strength was observed in sample A1 (1.3 MPa). Moreover, we observe differences within the same specimen (Fig. 6). Both the results of the compressive and flexural strength showed some dispersion within the same quarry and from one specimen to another with very high standard deviations. Similar results were found by [9] in Burkina Faso.

The effect of immersion of the specimens in water on the durability of the material was evident when the compressive strength test was carried out. The results show that the compressive strength of specimens immersed in water decreased with the increase in water content.

Similar results were reported by $[9,10,23]$. A negative, but very strong and significant correlation was recorded between the compressive strength of the immersed specimens and the degree of saturation $(r=-0.90)$. This means that when the degree of saturation increases, the compressive strength of the immersed specimens drops. In other words, the resistance decreases with the increase in the water content. The

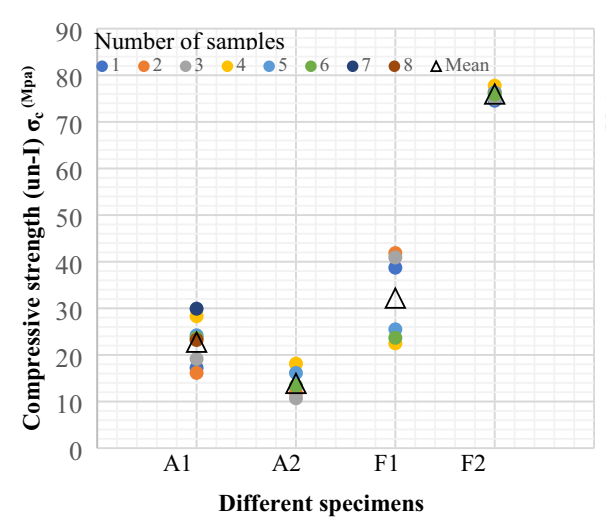

a

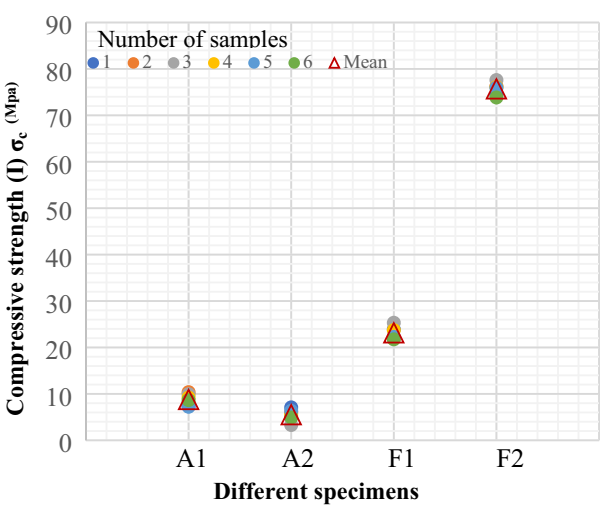

b

Fig. 5 a compressive strength of dry specimens according to different facies. $\mathbf{b}$ Compressive strength of water immersed specimens according to the different facies 


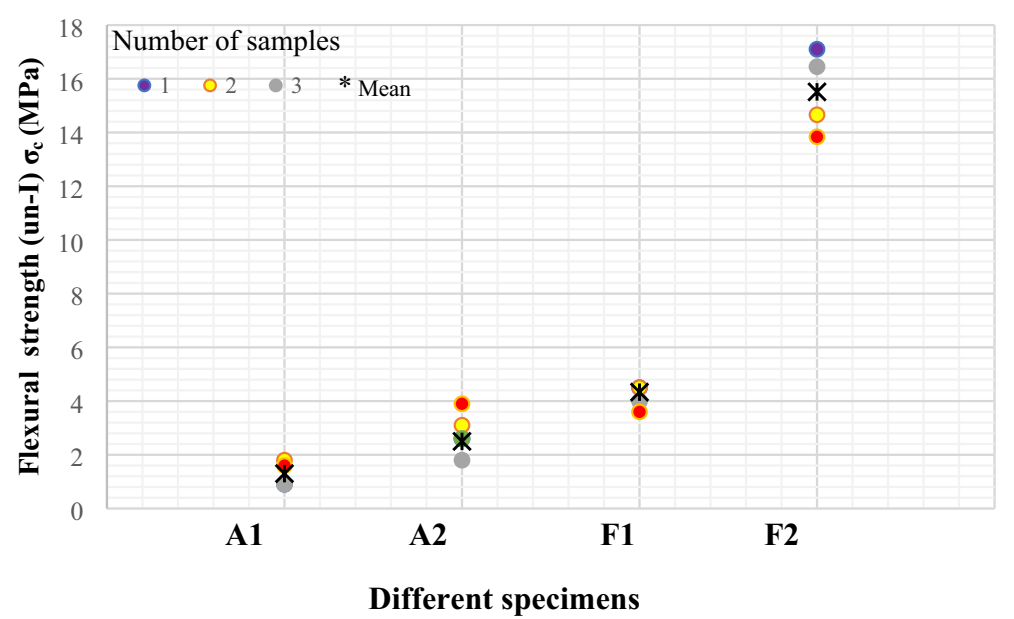

Fig. 6 Flexural strength of dry specimens according to the different facies. Kaol: kaolinite; Boe: Boemite; Gib: Gibbsite; Goe: Goethite; Hem: Hematite; An: Anatase; Mag: Magnetite

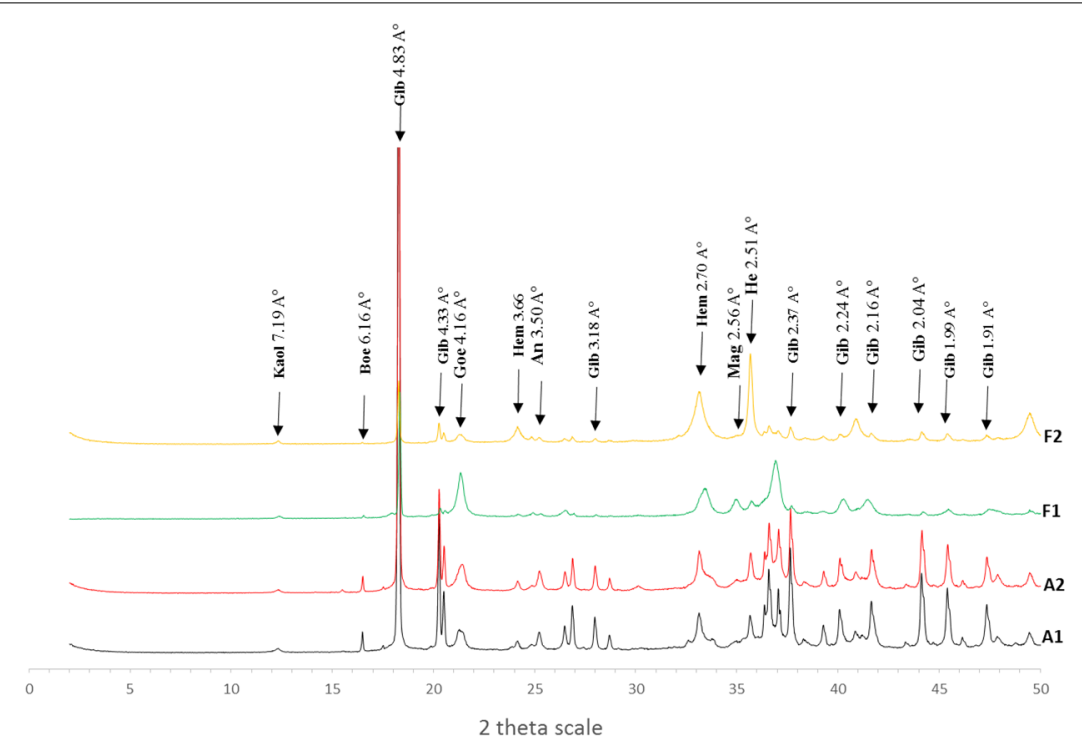

Kaol: kaolinite; Boe: Boemite; Gib: Gibbsite; Goe: Goethite; Hem: Hematite; An: Anatase; Mag: Magnetite Fig. 7 XRD patterns of laterite hardpans

only exception was with the F2 sample having a slight decrease, while the other samples present a remarkable reduction of resistance after immersion. The samples with high alumina content showed a drop in the compressive strength after immersion in water of between 60 and $61 \%$. This could be due to the fact that the aluminous minerals are more hydrated than iron minerals [24] which would easily facilitate their hydration with water and subsequently decrease the material strength. 
Table 3 Physical properties of the stone lateritic blocks of Bamendjou

\begin{tabular}{llllllllr}
\hline Quarry & samples & Nbr & \multicolumn{2}{l}{ Parameters } \\
\cline { 3 - 8 } & & & $\mathrm{P}\left(\mathbf{g} / \mathbf{c m}^{\mathbf{3}}\right)$ & $\mathbf{G s}$ & $\mathbf{W}_{\mathrm{w}}$ (\%) & $\mathbf{S}(\%)$ & $\mathbf{N}(\%)$ & $\mathbf{N}_{\mathbf{0}}$ (\%) \\
\hline Nkong-Thonta & F1 & 6 & $2.45 \pm 0.01$ & 3.69 & 1.17 & $54.16 \pm 1.9$ & $35.15 \pm 1.11$ & $19.04 \pm 0.79$ \\
Nkong-Kang & F2 & 6 & $3.01 \pm 0.04$ & 3.84 & 1.12 & $30.4 \pm 2.11$ & $21.47 \pm 1.11$ & $6.57 \pm 0.63$ \\
& A1 & 6 & $1.19 \pm 0.02$ & 2.8 & 0.4 & $52.08 \pm 4.42$ & $30.84 \pm 0.7$ & $16.06 \pm 1.42$ \\
Nkong-Ndang & A2 & 6 & $1.88 \pm 0.05$ & 3.16 & 0.6 & $63.75 \pm 1.01$ & $37.48 \pm 1.73$ & $23.89 \pm 1.20$ \\
\hline
\end{tabular}

Number of samples (Nbr)

Table 4 Mechanical properties of the lateritic hardpan specimens of Bamendjou

\begin{tabular}{lllll}
\hline Quarry & Facies & \multicolumn{3}{l}{ Mechanical properties } \\
\cline { 3 - 5 } & & State & Compressive (MPa) & Flexural (MPa) \\
\hline Nkong-Thonta & F1 & Un-Immersed & $32.18 \pm 9.20$ & $04.33 \pm 0.43$ \\
& & Immersed & $23.15 \pm 1.40$ & \\
Nkong-Kang & F2 & Un-Immersed & $75.97 \pm 1.13$ & $15.51 \pm 1.52$ \\
& A1 & Immersed & $75.70 \pm 1.35$ & \\
& & Un-Immersed & $22.73 \pm 4.96$ & $01.30 \pm 0.47$ \\
& A2 & Immersed & $08.79 \pm 1.30$ & $02.50 \pm 0.69$ \\
& & Un-Immersed & $13.89 \pm 2.76$ & \\
\hline
\end{tabular}

\section{Mineralogical and geochemical composition}

The X-ray diffraction (XRD) patterns of the four lateritic hardpans from Bamendjou are presented in Fig. 7 while the mineralogical and geochemical characteristics are shown in Tables 3 and 4 respectively. It can be noted that all samples have their major peaks assigned to gibbsite (Gib), goethite (Goe), and hematite (Hem). The minor peaks were assigned to kaolinite (Kaol) and anatase (An). Goethite is the second most abundant mineral in these specimens, and represents 10.45 and $20.59 \%$ of minerals detected by $\mathrm{X}$-ray. The results of the mineralogical analysis in Table 3 showed that lateritic hardpans exploited at three quarries in Bamendjou have significant proportions of iron oxide and hydroxide (goethite and hematite) and alumina (gibbsite). The A1 samples from the Nkong-Kang quarry and the A2 Nkong-Dang showed high levels of gibbsite $(81.58 \%$ and $66.39 \%$ respectively), hence the high percentage of $\mathrm{Al}_{2} \mathrm{O}_{3}(51.63 \%$ and $43.85 \%$ respectively). On the other hand, F1 of the Nkong-T'honta quarry and F2 of NkongKang have high $\mathrm{Fe}_{2} \mathrm{O}_{3}$ contents, resulting in $60.96 \%$ goethite and $48.04 \%$ hematite for the F1 and F2 samples, respectively. The high content in both the oxide and hydroxide is believed to be due to the humid tropical climate which occurs in the region which favors the allitization process. These hardpans have a different composition from the ones observed in Burkina Faso by Abhilash et al. [9] and in India by Kasthurba et al. [25]. The $\mathrm{Al}_{2} \mathrm{O}_{3}$ and $\mathrm{Fe}_{2} \mathrm{O}_{3}$ show opposing trends in the specimens while the $\mathrm{SiO}_{2}$ and $\mathrm{TiO}_{2}$ are almost constant as it is expected in most lateritic hardpans [4]. Meanwhile the following oxides $\mathrm{P}_{2} \mathrm{O}_{5}, \mathrm{MnO}, \mathrm{MgO}$ and $\mathrm{CaO}$ were present only in small amounts. It was also observed that the geochemistry also influences the mechanical charatersitics of the hardpans. For example the density and specific gravity though variable from from one 
quarry to another clearly indicates that the specimens F2 and F1 which are iron rich have higher values than specimens A1 and A2 which are alumina rich. From the geochemical composition of the quarry it was also found that laterites which are rich in iron oxide were also less porous, and are therefore more resistant. A positive, strong and significant correlation was recorded between dry compressive strength and the level of iron $(r=+0.72)$. The reverse was observed between dry compressive strength and total porosity $(r=-0.90)$. While within the same quarry, the geochemical composition and porosity vary considerably. This could also explain the variation of resistance in NkongKang quarry. In addition to the iron content, the mineralogical composition associated with low porosity is a very important factor. This could also be the difference between F1 and F2 specimens, because both contain the same value of iron oxide (58\%), but the difference in mineralogical composition (F1 is rich in goethite $60.96 \%$ and $\mathrm{F} 2$ in $48.04 \%$ hematite). The hardness of goethite $(\mathrm{FeO}(\mathrm{OH}))$ is 5-4.5, hematite $\left(\mathrm{Fe}_{2} \mathrm{O}_{3}\right)$ is 5.5-6.5, gibbsite $\mathrm{Al}(\mathrm{OH})_{3}$ is 3.0 and kaolinite $\left(\mathrm{Al}_{4}\left[\mathrm{Si}_{4} \mathrm{O}_{10}\right](\mathrm{OH})_{8}\right)$ is 2-2.5 [21, 26]. Linear correlations were established between natural compressive strength and hematite $\left(R^{2}=0.91\right)$. The variation in strength of Bamendjou laterite suggests the need for a development of a suitable classification system for building applications similar to that adopted in the case of lateritic stone blocks (LBS) based on the strength requirements as given in Burkina Faso by Lawane et al. [19].

\section{Correlation between the various parameters}

The correlation between the mechanical and physical properties, then mineralogical and geochemical parameters is given by the Pearson coefficient shown in Table 5 .

It is deduced from this table that

- A very negative correlation was found between the total porosity and the dry compressive strength $(r=-0.90)$ at a significant threshold of $p<0.05$. Similarly, strong negative correlations were obtained for the water immersed compressive strength $(\mathrm{r}=-0.89)$, and flexural strength $(\mathrm{r}=-0.84)$.

- A very negative correlation was found between the saturation ratio and the immersed compressive strength $(\mathrm{r}=-0.94)$ at a significant threshold of $\mathrm{p}<0.05$.

- A positive strong correlation was found between $\mathrm{Fe}_{2} \mathrm{O}_{3}$ and the dry compressive strength $(r=+0.72)$ at a significant threshold of $\mathrm{p}<0.05$. Similarly, strong positive correlations were obtained for the water immersed compressive strength $(r=+0.69)$, and flexural strength $(r=+0.70)$.

- A negative strong correlation was found between $\mathrm{Al}_{2} \mathrm{O}_{3}$ and the dry compressive strength $(r=-0.64)$ at a significant threshold of $\mathrm{p}<0.05$. Similarly, strong positive cor-

Table 5 Matrix of correlation between different parameters

\begin{tabular}{llllll}
\hline Parameters & Total porosity & Saturation ratio & $\mathrm{Fe}_{\mathbf{2}} \mathbf{O}_{\mathbf{3}}$ & $\mathbf{A l}_{\mathbf{2}} \mathbf{O}_{\mathbf{3}}$ & Hematite \\
\hline Mechanical properties & & & & \\
Natural compressive strength & $r=\left(-0.90^{\mathrm{b}}\right)$ & & $r=\left(+0.72^{\mathrm{b}}\right)$ & $\mathrm{r}=\left(-0.64^{\mathrm{b}}\right)$ & $\mathrm{r}=\left(+0.94^{\mathrm{b}}\right)$ \\
Saturated compressive strength & $\mathrm{r}=\left(-0.89^{\mathrm{b}}\right)$ & $r=\left(-0.94^{\mathrm{b}}\right)$ & $\mathrm{r}=\left(+0.69^{\mathrm{b}}\right)$ & $\mathrm{r}=\left(-0.61^{\mathrm{a}}\right)$ & $\mathrm{r}=\left(+0.97^{\mathrm{b}}\right)$ \\
Flexural strength & $r=\left(-0.84^{\mathrm{b}}\right)$ & & $r=\left(+0.70^{\mathrm{b}}\right)$ & $\mathrm{r}=\left(-0.66^{\mathrm{a}}\right)$ & $\mathrm{r}=\left(+0.99^{\mathrm{b}}\right)$ \\
\hline
\end{tabular}

$R$, Coefficient of correlation; ${ }^{a}$ threshold of significance $\left(p^{>} 0.01\right) ;{ }^{b}$ threshold of significance $\left(p^{>} 0.05\right)$ 


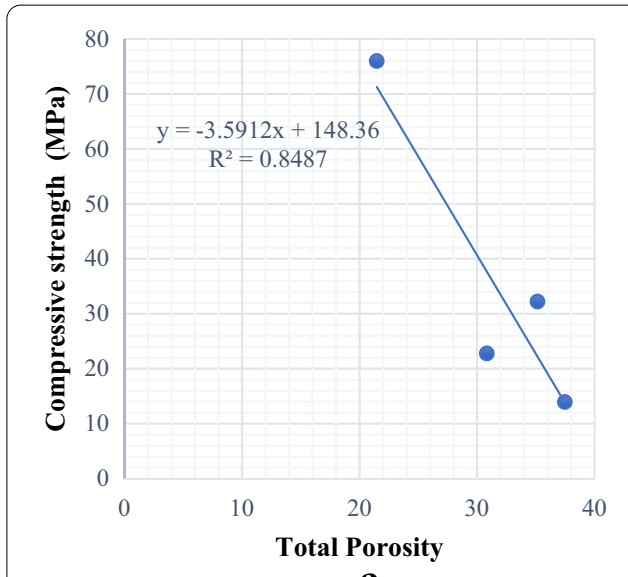

a

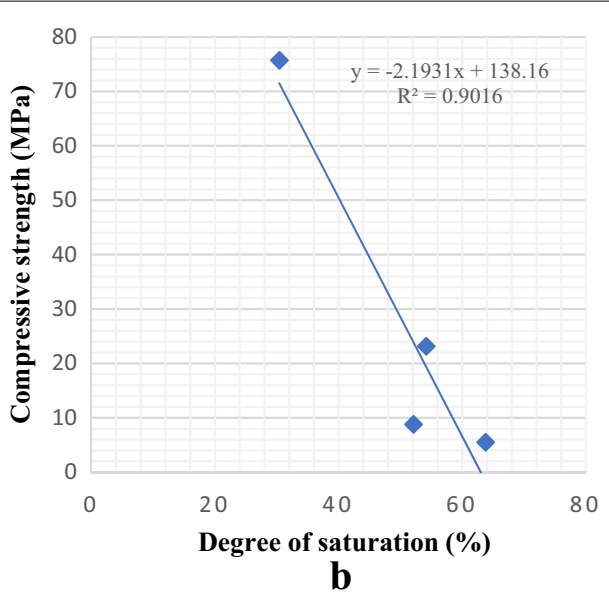

b

Fig. 8 a Influence of porosity on compressive strength of dry specimens. b Influence of degree of saturation on of the compressive strength of water immersed specimens

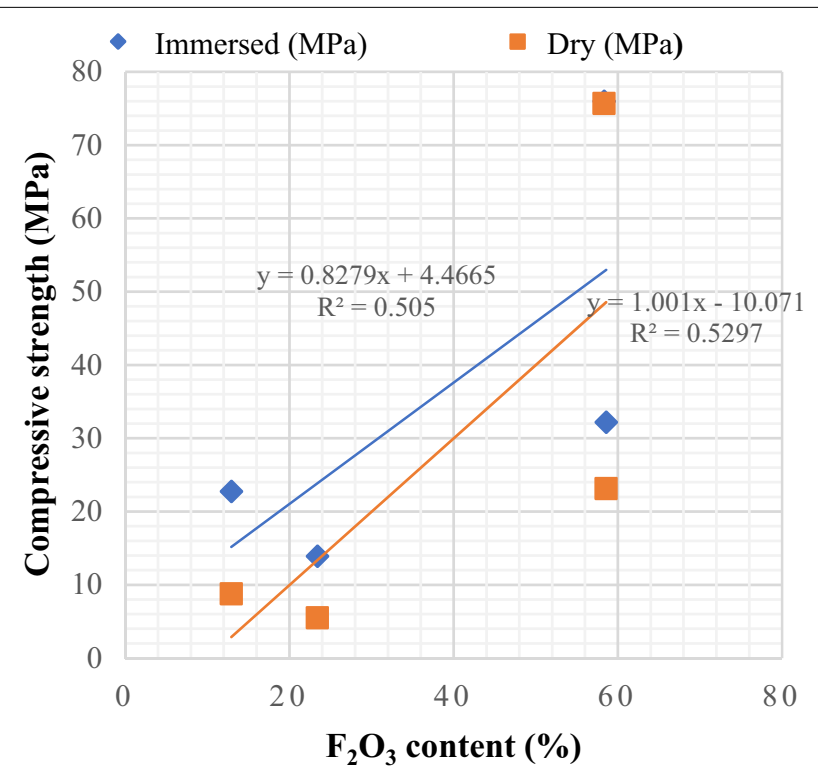

Fig. 9 Influence of $\mathrm{F}_{2} \mathrm{O}_{3}$ content on dry and immersed compressive strength

relations were obtained for the water immersed compressive strength $(r=-0.61)$, and flexural strength $(r=-0.60)$ at a significant threshold of $p<0.01$. And finally, a positive strong correlation was found between Hematite and the dry compressive strength $(\mathrm{r}=+0.94)$ at a significant threshold of $\mathrm{p}<0.05$. Also, strong positive correlations were obtained for the water immersed compressive strength $(r=+0.97)$, and flexural strength $(r=+0.99)$. 


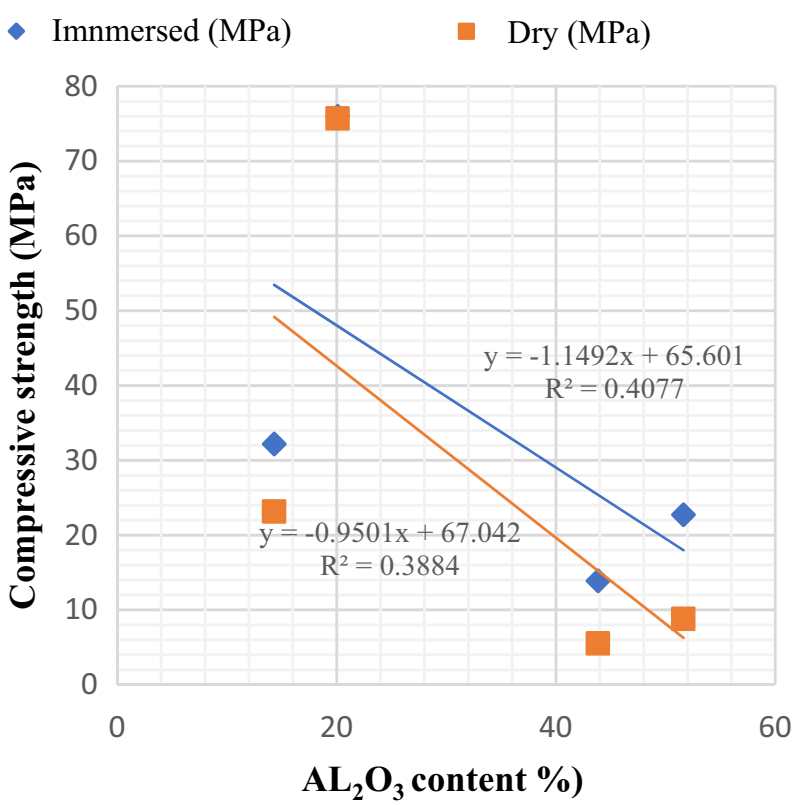

Fig. 10 Influence of $\mathrm{Al}_{2} \mathrm{O}_{3}$ content on dry and immersed compressive strength

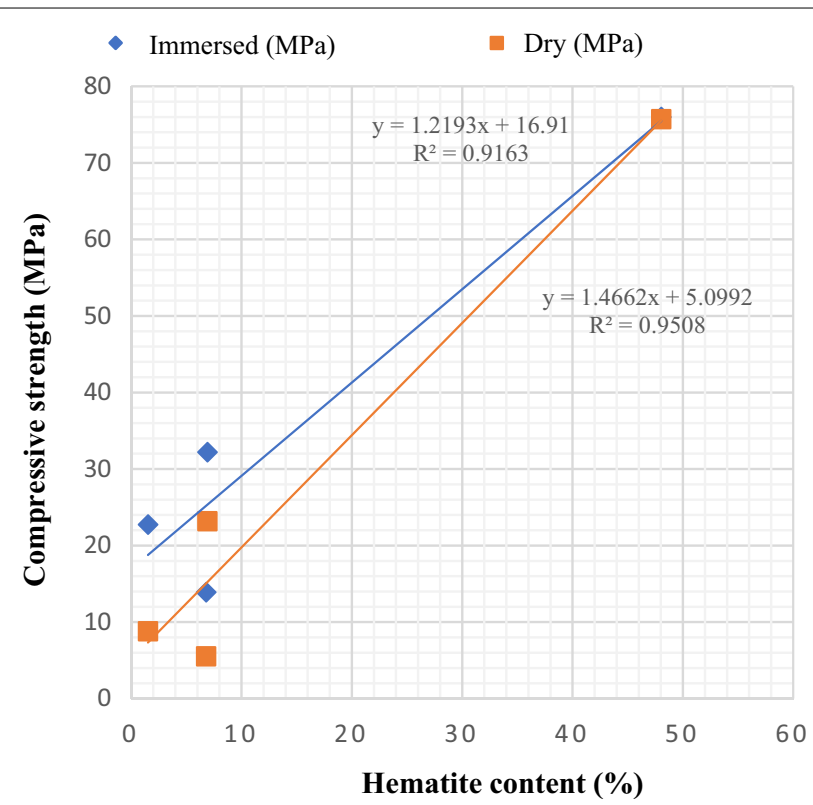

Fig. 11 Influence of Hematite content on dry and immersed compressive strength

The influence of the physical, mineralogical and geochemical properties on the mechanical properties

The influence of the physical, geochemical and mineralogical properties on the mechanical properties are shown in Figs. 8, 9, 10 and 11. It comes out from these figures that except for the lines from the Fig. 8 and 10, all the other figures present linear lines of average relationship with negative slope. 
Table 6 Resistance of material lost after saturation and gibbsite content

\begin{tabular}{lcrrr}
\hline Characteristics (\%) & \multicolumn{2}{l}{ Specimens } & & \\
\cline { 2 - 5 } & A1 & A2 & F1 & F2 \\
\hline Loss in resistance after immersion & 13.94 & 8.38 & 9.03 & 0.27 \\
$\begin{array}{l}\text { Percentage loss in resistance after immersion } \\
\text { (\%) }\end{array}$ & 61.32 & 60.00 & 28.60 & 0.35 \\
Total porosity & & & & \\
Open porosity & 30.84 & 37.48 & 35.15 & 21.47 \\
Hematite (\%) & 16.09 & 23.89 & 19.04 & 6.57 \\
Gibbsite level (\%) & 6.79 & 1.53 & 6.9 & 48.04 \\
\hline
\end{tabular}

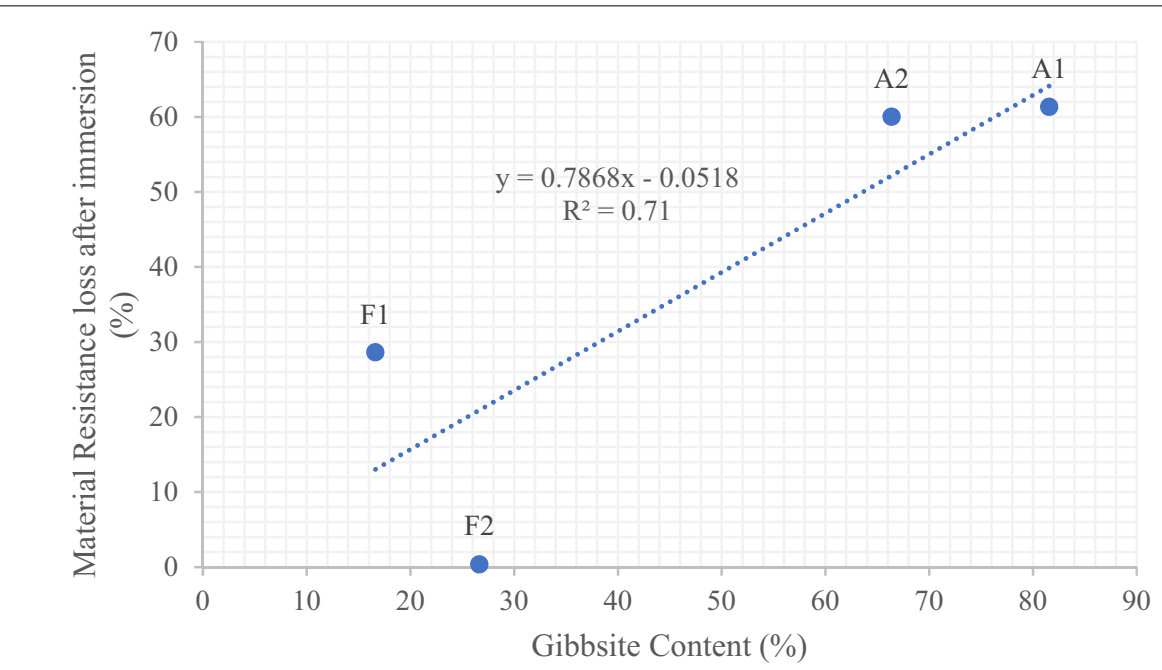

Fig. 12 Influence of gibbsite content on the resistance of material lost after saturation

\section{Influence of gibbsite content on the compressive strength of material lost after water} immersion

Table 6 presents the percentage of resistance in compression of material lost after immersion in water and the gibbsite content of material. It is deduced from this table that, the compressive strength of the A1 samples and A2 present a reduction of 61 and $60 \%$ respectively after immersion in water. The F2 sample is almost null because the load was not sufficient to cause the damage of material even after saturation. The A1 specimen presents a total porosity which is accessible to water and lower than F1 specimen, but which is more affected by water than F1 specimen (61.30\% and $28.60 \%)$. The Influence of gibbsite content on the resistance of material lost after immersion in water is shown in Fig. 12. It comes out that, this figure present linear lines of average relationship with positive slope. 


\section{Conclusion}

The aim of this study was to characterize four lateritic hardpan specimens coming from three quarries situated at Kong-Thonta; Kong-Kang and Kong Dang in Bamendjou sub-division of the West Region of Cameroon. The values of the bulk density are very variable from one specimen to another ranging from 1.88 to $3.01 \mathrm{~g} / \mathrm{cm}^{3}$. The specific gravity are also very high and variable from one quarry to another ranging from a value of 2.8 to 3.84 . Both open and total porosity parameters of the specimen varied from one specimen to the other within the same quarry. The total porosity of the F2 specimen from Kong-Kang quarry is lower than that of the other quarries. The results of the mechanical properties of the compressive strength tested dry were all above that Lateritic Block Stones (LBS) found in Burkina Fasa and India with values ranging from 1 to $4 \mathrm{MPa}$. The minimum compressive strength of the hardpans was $13.89 \mathrm{MPa}$ which is far superior to the ones found in Burkina Faso and India and therefore would be convenient for dwelling units. It is good to note that the European standard EN 777-1 [22] prescribes a minimum of $2.3 \mathrm{MPa}$ for the compressive strength of bricks, while the French norms NFP 13-304 [27] prescribes values of 6-60 MPa for densely vibrated bricks and 1.5-7 MPa for lightly vibrated bricks. The flexural strengths of the specimens were different from each other with the minimum value of $1.3 \mathrm{MPa}$ obtained for the A1 specimen. The F2 specimens gave the highest values of both the compressive and flexural strength followed by the $\mathrm{F} 1$ specimens. The predominant oxides in this laterite are $\mathrm{Al}_{2} \mathrm{O}_{3}, \mathrm{Fe}_{2} \mathrm{O}_{3}$ and $\mathrm{SiO}_{2}$, as well as other oxides such as $\mathrm{SiO}_{2}$, $\mathrm{TiO}_{2} \mathrm{P}_{2} \mathrm{O}_{5}, \mathrm{MnO}, \mathrm{MgO}$ and $\mathrm{CaO}$ in minor quantities. The major minerals found in the hardpans were gibbsite, goethite and hematite. The mineralogical and geochemical composition are variable from one quarry to another and these both influenced the characteristics of the hardpans such as the physical and mechanical properties, with the iron rich hardpans giving better charateristics than the alumina rich hardpans.

Acknowledgements

We would like to thank the Académie de Recherche pour l'Enseignement Supérieure (ARES) for their partial support under the project : Stage en valorisation des ressources secondaires pour une construction durable.

Authors' contributions

All authors read and approved the final manuscript.

\section{Declarations}

Competing interests

The authors declare that there is no conflict of interest.

Author details

${ }^{1}$ Department of Earth Sciences, Faculty of Science, University of Dschang, P.O Box 67, Dschang, Cameroon. ${ }^{2}$ Department of Civil \& Environmental Engineering, FEIT, University of Namibia, P.O Box 3624, Ongwediva, Namibia. ${ }^{3}$ Department of Civil Engineering, Fotso Victor University Institute of Technology Bandjoun, University of Dschang, Bandjoun, Cameroon.

Received: 12 January 2021 Accepted: 31 August 2021

Published online: 07 January 2022

\section{References}

1. Buchanan F (1807) A journey from madras through the countries of Mysore, Canara and Malabar, 2nd edn. East Indian Company, London, pp 436-560

2. Fosso J, Ménard J, Bardintzeff JM, Wandji P, Bellon H (2000) Le stratovolcan de Bangou (Ouest Cameroun): une serie transitionnelle, dans la ligne du Cameroun in: $18^{\text {ème }}$ Réunion des sciences de la Terre, Paris. p. 133 
3. Edlinger W (1908). Contribution to geology and petrography of the German Adamawa (Doctoral dissertation, Ph. D. Thesis, Erlangen University, Erlangen)

4. Gidigasu M (ed) (2012) Laterite soil engineering : pedogenesis and engineering principles, vol 9. Amsterdam, Elsevier

5. Morin S (1987). Cuirasses et reliefs de l'ouest Cameroun. In Séminaire régional sur les latérites: sols, matériaux, minerais (pp. 107-119).

6. Tchamba AB, Yongue R, Melo UC, Kamseu E, Njoya D (2008) Caractérisation de la bauxite de Haléo-Danielle (MinimMartap, Cameroun) en vue de son utilisation industrielle dans les matériaux à haute teneur en alumine. Silic Indus 5-6:77-84

7. Nyemb BJF, Onana VL, Ntoh NG, Pianta Tadida C, Ekodeck GE (2013) Caractérisation minéralogique, chimique et géotechnique des graveleux latéritiques du tronçon routier Bahouan-Bamendjou-Batchum (Ouest Cameroun). Université de Douala, Cameroun, Colloque Géosciences et Appui au Développent

8. Sikali F, Emerati MD (1986) Utilisation des latérites en techniques routières au Cameroun. Acte du séminaire régional sur les latérites: Douala-Cameroun, pp. 277-288

9. Abhilash HN, McGregor F, Millogo Y, Fabbri A, Séré AD, Aubert JE, Morel JC (2016) Physical, mechanical and hygrothermal properties of lateritic building stones (LBS) from Burkina Faso. Constr Build Mater 125:731-741. https://doi. org/10.1016/j.conbuildmat.08.082

10. Gana LA (2014) Caractèrisation des matériaux latéritiques indurés pour une meilleure utilisation dans I'habitat en Afrique (Doctoral dissertation, Le Havre)

11. Lawane A, Pantet A, Vinai R, Thomassin JH (2011). Etude géologique et géomécanique des latérites de Dano (Burkina Faso) pour une utilisation dans l'habitat

12. Gribble CD (1988) The classification of minerals. In: Rutley's elements of mineralogy. Springer, Dordrecht, pp. $147-149$

13. NF P94-050 (1995) Soils: recognition and tests—determination of water content by weight—drying method

14. UNE-EN 1936 (2007) Standard Metodos de ensayo para piedra natural. Determinacion de la densidad real y aparente y de la porosidad abierta y total. AENOR, Madrid

15. EN 13722 (2001) Méthodes d'essai pour pierres naturelles—Détermination de la l'absorption d'eau a la pression atmospheric

16. EN 1926 (1999) Méthodes d'essai pour pierres naturelles—Détermination de la résistance en compression, Comité Européen de Normalisation. p. 16

17. EN 12372 (2007) Méthodes d'essai pour pierres naturelle - Détermination de la résistance en flexion sous charge centrée, Comité Européen de Normalisation. p. 19

18. Brown G (1982) Crystal structures of clay minerals and their X-ray identification, vol 5. The Mineralogical Society of Great Britain and Ireland

19. Lawane A, Vinai R, Pantet A, Thomassin JH, Messan A (2014) Hygrothermal features of laterite dimension stones for sub-Saharan residential building construction. J Mater Civ Eng 26(7):05014002

20. Vázquez P, Alonso FJ, Carrizo L, Molina E, Cultrone G, Blanco M, Zamora I (2013) Evaluation of the petrophysical properties of sedimentary building stones in order to establish quality criteria. Constr Build Mater 41:868-878

21. Kasthurba AK, Santhanam M, Achyuthan H (2008) Investigation of laterite stones for building purpose from Malabar region, Kerala, SW India-Chemical analysis and microstructure studies. Constr Build Mater 22(12):2400-2408

22. EN 777-1 (2003) AFNOR. Spécification des éléments en maçonnerie

23. Kasthurba AK (2006) Characterization and study of weathering mechanisms of malabar laterite for building purposes (Doctoral dissertation, PhD thesis, Indian Institute of Technology Madras, unpublished)

24. Momo MN, Tematio P, Yemefack M (2012) Multi-scale organization of the doumbouo-fokoué bauxites ore deposits (West Cameroon): implication to the landscape lowering. Open J Geol 2:14-24

25. Kasthurba AK, Reddy KR, Venkat R (2014) Use of Laterite as a sustainable building material in developing countries

26. Reddy DV (1996). Decorative and dimensional stones of India. CBS Publishers \& Distributors

27. NFP 13-304 (1983) Briques en terre cuite destinées à rester apparentes. NFP 13-304

\section{Publisher's Note}

Springer Nature remains neutral with regard to jurisdictional claims in published maps and institutional affiliations.

\section{Submit your manuscript to a SpringerOpen ${ }^{\circ}$ journal and benefit from:}

- Convenient online submission

- Rigorous peer review

- Open access: articles freely available online

- High visibility within the field

- Retaining the copyright to your article

Submit your next manuscript at $>$ springeropen.com 